www.jmscr.igmpublication.org

Impact Factor (SJIF): 6.379

Index Copernicus Value: 79.54

ISSN (e)-2347-176x ISSN (p) 2455-0450

crossrefDOI: https://dx.doi.org/10.18535/jmscr/v6i9.08

Journal Of Medical Science And Clinical Research

\title{
Histopathological Audit of Appendectomy Specimens
}

\author{
Author \\ Dr (Colonel) Gurmeet Singh Sarla \\ MH DEVLALI \\ Email: rijak1@gmail.com, Mobile: 9882562223
}

\begin{abstract}
Emergency Appendicectomy is the most commonly performed surgery world over. A retrospective study was carried out to determine various histopathological diagnoses, their demographics and negative appendectomyover a period of two years in a peripheral hospital. A total of 9lappendectomies were done over a period of two years in a peripheral hospital in Nasik, India. Out of the 91 patients who underwent appendectomy, 63 patients were males and 28 patients were females. In our series the highest incidence occurred in the age group of 20-30 years. The most frequently removed specimen of appendix was $6 \mathrm{~cm}$ in length. Males were more commonly affected. The most common histopathology report revealed numerous neutrophils infiltrating into the muscularis propria extending upto serosa. Negative appendectomies were $18.68 \%$ and females were more commonly operated for negative appendectomies (70.58\%).

Keywords: Acute Appendicitis, Appendectomy, Histopathology.
\end{abstract}

\section{Introduction}

The Vermiform Appendix is a tubular structure attached to the base of caecum at the confluence of taenia coli. It is approximately $8-10 \mathrm{~cm}$ long in adults and represents the underdeveloped distal end of large caecum seen in other animals. In humans it is regarded as a vestigial organ and acute inflammation of this structure is called as acute appendicitis. Despite advances in technology and imaging modalities, there is dilemma in the clinical diagnosis of acute appendicitis. Histopathological examination still remains the gold standard method for the confirmation of appendicitis. The aim of this study is to audit the surgically removed appendices labelled clinically and/or sonologically labelled as acute appendicitis.

\section{Materials and Methods}

This is a retrospective study and all surgically resected appendices submitted for histopathology were included in the study.

All emergency appendectomies, interval appendectomies and incidental appendectomies which were performed along with other abdominopelvic surgeries were included.

Negative appendectomy was defined as one which is performed for a clinical or sonological diagnosis of acute appendicitis but in which the appendix is found to be normal on histopathological examination with no evidence of inflammation.

\section{Results}

A total number of 91 patients underwent Appendicectomy over a period of two years in the 
department of surgery of a peripheral hospital in Nasik, India.2 appendicectomies were done as interval appendicectomies and 2 were done as part of Exploratory laparotomy. Remaining 87 appendectomies were done for acute appendicitis. Out of the 91 patients operated upon, 63 patients $(69.23 \%)$ were males and 28 patients $(30.76 \%)$ were females.

The highest incidence, 37 patients $(40.65 \%)$ occurred in the age group of 20-30 years.

$26(28.57 \%)$ specimens removed were $6 \mathrm{~cm}$ in length. The largest specimen removed was $10 \mathrm{~cm}$ long and the smallest one was $2 \mathrm{~cm}$.

The most common histopathology report $(59.34 \%)$ i.e. 54 reports revealed numerous neutrophils infiltrating into the muscularis propria extending upto serosa.

Negative appendectomies were $18.68 \%$ and females were more commonly operated for negative appendectomies (12 out of 17 i.e. $70.58 \%$ )

$2(2.19 \%)$ specimens showed fecoliths and calcification.

$2(2.19 \%)$ specimens lumen showed vegetable matter.

$2(2.19 \%)$ specimens showed gangrenous appendices.

$2(2.19 \%)$ specimens showed marked fibrosis with wall infiltration of acute inflammatory infiltrate. These specimens were removed as appendectomy done for Interval appendectomy.

Table 1: Incidence of Acute Appendicitis over a period of 2 years: Age and Sex distribution

\begin{tabular}{|l|c|c|}
\hline Age group & Males & Females \\
\hline $0-10$ years & 4 & 4 \\
\hline 10-20 years & 7 & 1 \\
\hline 20-30 years & 26 & 11 \\
\hline 30-40 years & 19 & 4 \\
\hline 40-50 years & 3 & 2 \\
\hline $50-60$ years & 2 & 3 \\
\hline $60-70$ years & 2 & 3 \\
\hline Total & 63 & 28 \\
\hline
\end{tabular}

Table 2: Size of Appendix specimen:

\begin{tabular}{|l|c|c|c|}
\hline Size & Males & Females & Total cases \\
\hline $2 \mathrm{~cm}$ & 4 & 2 & 6 \\
\hline $3 \mathrm{~cm}$ & 5 & 2 & 7 \\
\hline $4 \mathrm{~cm}$ & 7 & 2 & 9 \\
\hline $5 \mathrm{~cm}$ & 12 & 4 & 16 \\
\hline $6 \mathrm{~cm}$ & 18 & 8 & 26 \\
\hline $7 \mathrm{~cm}$ & 5 & 5 & 10 \\
\hline $8 \mathrm{~cm}$ & 4 & 4 & 8 \\
\hline $9 \mathrm{~cm}$ & 4 & - & 4 \\
\hline $10 \mathrm{~cm}$ & - & 5 & 5 \\
\hline Total & 59 & 32 & 91 \\
\hline
\end{tabular}

Table 3: Histopathology report

\begin{tabular}{|l|l|c|}
\hline $\begin{array}{l}\text { S } \\
\text { No }\end{array}$ & Histopathology report & $\begin{array}{c}\text { Number } \\
\text { of cases }\end{array}$ \\
\hline 1 & $\begin{array}{l}\text { Numerous Neutrophils infiltrating into } \\
\text { the muscularis propria extending upto } \\
\text { serosa }\end{array}$ & 54 \\
\hline 2 & $\begin{array}{l}\text { Numerous Neutrophils and Eosinophils } \\
\text { infiltrating into the muscularis propria } \\
\text { extending upto serosa }\end{array}$ & 6 \\
\hline 3 & $\begin{array}{l}\text { Numerous Eosinophils and Plasma cells } \\
\text { infiltrating into the muscularis propria } \\
\text { extending upto serosa }\end{array}$ & 6 \\
\hline 4 & Lumen shows Fecolith and calcification & 2 \\
\hline 5 & Lumen shows vegetable matter & 2 \\
\hline 6 & Gangrenous Appendix & 2 \\
\hline 7 & $\begin{array}{l}\text { Marked fibrosis, wall infiltration of } \\
\text { acute inflammatory infiltrate }\end{array}$ & 2 \\
\hline 8 & Histology consistent with Appendix & 17 \\
\hline
\end{tabular}

\section{Discussion}

The cause of acute appendicitis is unknown but is probably multifactorial. Luminal obstruction, dietary and familial factors have all been suggested $^{1}$. When luminal obstruction occurs, intraluminal pressure surpasses that in the appendiceal veins, causing venous outflow obstruction. Finally ischemia develops in the appendiceal wall which weakens the epithelial integrity and increases the organ's risk of bacterial invasion. Lymphoid hyperplasia and fecoliths are the most common cause of luminal obstruction.

Appendicitis is the most common abdominal emergency and accounts for more than 40000 hospital admissions in England every year ${ }^{2}$. This makes the appendix one of the most commonly received specimen in the histology department. The life time risk of appendicitis is 7\%, commonly occurring in adolescents and young adults $^{5}$. Appendicitis is most common in the age 
group of 10-20 years but no age is exempt ${ }^{3}$. Diagnostic sequence of abdominal pain, followed by vomiting with migration of pain to right iliac fossa was first described by Murphy but may be present in only $50 \%$ of patients ${ }^{4}$. Percussion tenderness, guarding and rebound tenderness are most reliable clinical findings indicating a diagnosis of acute appendicitis ${ }^{5}$. The diagnosis is predominantly a clinical one ${ }^{8}$. As ultrasonography studies are operator dependent and need careful examination, use of computed tomography in preference to ultrasonography is recommended as it has a greater diagnostic accuracy ${ }^{7,9}$.

The rate of acute appendicitis varies among countries. Declining rates have been reported in the United states and Europe ${ }^{6}$.In developing countries, the incidence is increasing in most urban centres, probably due to adoption of western $\operatorname{diet}^{10}$.

Despite advances in technology and imaging modalities, there is dilemma in the clinical diagnosis of acute appendicitis. Histopathological examination still remains the gold standard method for the confirmation of appendicitis.

The diagnosis of acute appendicitis relies on an evaluation of the patient's history, laboratory and radiologic findings, as well as the surgeon's subjective judgment based on experience. However, the reported rates of histology-proven negative cases following appendectomy have ranged between $9.2 \%$ and $35.0 \%{ }^{11}$. The rates of negative cases are particularly high for women during child-bearing years ${ }^{11}$. The rate of negative appendectomy found in the current study $(18.68 \%)$ is comparable to that in the collective literature. However, if patients requiring surgery are denied the procedure in order to avoid the risk of performing a negative laparotomy, there may be an increased risk of undesirable clinical events, such as perforation.

\section{Conclusion}

The incidence of Acute Appendicitis is more common in males as compared to females. The highest incidence occurs in the age group of 20-30 years. The most frequently removed specimen of Appendix was $6 \mathrm{~cm}$ in length. The most common histopathology report revealed numerous Neutrophils infiltrating into the muscularis propria extending upto serosa. Negative appendectomies were $18.68 \%$ and females were more commonly operated for negative appendectomies (12 out of 17 i.e. $70.58 \%$ )

\section{References}

1. Larner AJ. The aetiology of appendicitis. Br J Hosp Med 1988; 39:540-2. (Pubmed)

2. Hospital Episode Statistics. Primary Diagnosis:

summary.www.hesonline.nhs.uk/Ease/serv let/contentserver/siteid=1937\&categoryid= 202(accessed 28 Aug 2006)

3. Addiss DG, Shaffer N, Fowler BS, Tauxe $\mathrm{RV}$. The epidemiology of appendicitis and appendectomy in United States, Am J Epidemiol 1990, 132 :910-25 (Pubmed)

4. Murphy J. Two thousand operations for appendicitis, with deductions from his personal experience. Am J Med Sci 1904; 128: $187-211$

5. Turner JR. The Gastrointestinal tract, In: Kumar,Abbas,Fausto (eds). Robins and Cotran Pathologicbasis of disease. 8th edn. Saunders: Philadelphia; 2010. pp870-1.

6. Al-Omran M, Mamdani MM, McLeod RS. Epidemiologic features of acute appendicitis in Ontario, Canada. Can J Surg2003;46:263-8.

7. Terasawa $\mathrm{T}$, Blackmore $\mathrm{CC}$, Bent $\mathrm{S}$, Kohlwes RJ: Systematic review: Computed tomography and ultrasonography to detect acute appendicitis in adults and adolescents. Ann Int Med 2004; 141: 537-46 (Pubmed)

8. Acute Appendicitis. DJ Humes, Research into Ageing/ Royal College of Surgeons of England research fellow and J Simpson, lecturer in surgery

9. Weston A, Jackson $\mathrm{T}$, Blamey S. Diagnosis of appendicitis in adults by 


\section{JMSCR Vol||06||Issue||09||Page 47-50||September}

ultrasonography and computed tomography: a systematic review and meta- analysis. Int J Technol assess Health care 2005;21: 368-79 (Pubmed)

10. Oguntola AS, Adeoti ML, Oyemolade TA. Appendicitis: Trends in incidence, age, sex, and seasonal variations in SouthWestern Nigeria. Ann Afr Med 2010;9: 213-7.

11. Khairy G. Acute appendicitis: is removal of a normal appendix still existing and can we reduce its rate? Saudi J Gastroenterol 2009;15(3):167-170. 